\title{
Analysis of the essential oils from Calendula officinalis growing in Brazil using three different extraction procedures
}

\author{
Zilda Cristina Gazim¹, Claudia Moraes Rezende², Sandra Regina Fraga², Benedito Prado Dias \\ Filho $^{3}$, Celso Vataru Nakamura ${ }^{3}$, Diógenes Aparicio Garcia Cortez ${ }^{3^{*}}$ \\ ${ }^{1}$ Departamento de Farmácia, Universidade Paranaense, ${ }^{2}$ Instituto de Química Universidade Federal do Rio de \\ Janeiro, ${ }^{3}$ Departamento de Farmácia e Farmacologia, Universidade Estadual de Maringá
}

*Correspondence:

D. A. G. Cortez

Department of Pharmacy and

Pharmacology,

Universidade Estadual de Maringá, Av.

Colombo, 5790,

87020-900, Maringá, PR, Brazil

E-mail: dagortez@uem.br
Terpenes and aroma volatiles from flowers of Calendula officinalis cultivated in southeastern Brazil were obtained by steam distillation (SD), headspace-cold finger (HS-CF) extraction and headspace solid-phase microextraction (HS-SPME) coupled with gas chromatography and mass spectrometric analysis. The dried flowers contained $0.1 \%$ oil. Kovats indices and mass spectra were used to identify 27 individual components in the various volatile fractions. The main components present in the volatile fractions of the C. officinalis flowers, obtained by SD, HS-SPME, and HS$C F$, were $\delta$-cadinene $(22.5,22.1$, and $18.4 \%)$ and $\gamma$-cadinene (8.9, 25.4 , and $24.9 \%$ ) while $20.4 \%$ of $\alpha$-cadinol was seen only after SD extraction.
Uniterms

- Calendula officinalis L

- Gas chromatography-mass spectroscopy

- Steam distillation

- Headspace solid-phase microextraction

- Headspace-cold finger

\section{INTRODUCTION}

Calendula officinalis (Asteraceae) is an annual herb with yellow to orange flowers, native to Mediterranean region. It is also known as pot marigold, a name historically associated with its use in soups and stews to combat illnesses (Ramos et al., 1988). Nowadays, C. officinalis is approved for food use in U.S.A. and appears in the Food and Drug Administration's list of GRAS (Generally Recognized as Safe) substances. Because of its long history of safety as a medicine for the treatment of inflammations and skin wounds (Della Loggia et al., 1994), a number of reports describe its use for innumerable ailments. As a bonus, the beautiful calendula flowers are frequently seen and easily grown in home gardens all over the world (Ramos et al., 1988).

Sesquiterpene glycosides, saponins, xanthophylls, triol triterpenes, flavonoids, and volatiles are observed in its composition. Chalchat et al. (1991) studied the essential oil of $C$. officinalis flowers cultivated in the Massif Central, France, and obtained sesquiterpene alcohol and, mainly, $\alpha$-cadinol using steam distillation. Radulescu et al. (2000) analyzed flowers from Romania by headspace and steam distillation, where $\delta$-cadinene plus 1,3,5-cadinatriene and $\alpha$-muurolol were found as major compounds.

Because of the economic value of $C$. officinalis as an herbal medicine and its use in cosmetics, perfumery, pharmaceutical preparations, and food, we decided to study the composition of essential oil of $C$. officinalis growing in southeastern Brazil. Three different extraction techniques were used to investigate the volatiles, including steam distillation (SD), headspace solid-phase micro extraction (HS-SPME), and headspace-cold finger (HS$\mathrm{CF}$ ) extraction, in association with gas chromatographymass spectrometry (GC-MS and GC-FID). 


\section{MATERIAL AND METHODS}

\section{Experimental}

\section{Plant material}

The flowers of Calendula officinalis were collected from an experimental plot in the medicinal botanical garden of the Universidade Paranaense in Umuarama, Brazil, at S23 ${ }^{\circ}$ $46.225^{\prime}$ and $\mathrm{W} 53^{\circ} 16.730^{\prime}$, and an altitude of $391 \mathrm{~m}$. A voucher specimen, 1311, was deposited at the educational herbarium of the Universidade Paranaense (HEUP). Seeds were planted on 30 April 2004 (during autumn), and collection began on 20 July (winter), three months after planting.

The flowers were dried on mats in the shade and at room temperature, spread into thin layers that were not mixed over the 10-day drying period. After this interval, water loss by both drying and desiccation, according to techniques described in the pharmacopoeia, was determined (Farmacopéia Brasileira, 1988).

Three samples each were used for extraction by steam distillation, HS-SPME, and HS-C, respectively.

\section{Instrumentation}

- GC-MS

Oil qualitative analyses and volatile fractions were carried out using an Agilent 6890 Series II gas chromatograph (Palo Alto, U.S.A.) coupled to an Agilent 5973 quadrupole mass spectrometer with electron ionization mode (EI) generated at $70 \mathrm{eV}$ (ion source at $230{ }^{\circ} \mathrm{C}$ and transfer line at $\left.280^{\circ} \mathrm{C}\right)$. The $\mathrm{GC}$ was performed using a J\&W DB-5 (5\% diphenyl-95\% dimethyl silicone) capillary column ( $30 \mathrm{~m} \times 0.25 \mathrm{~mm}$ i.d. $\times 0.25 \mu \mathrm{m}$ film), and helium was used as a carrier gas $\left(1 \mathrm{~mL} \mathrm{~min}^{-1}\right)$. The initial temperature was programmed from $35^{\circ} \mathrm{C}$ to $60^{\circ} \mathrm{C}$ (at $1^{\circ} \mathrm{C}$ $\left.\mathrm{min}^{-1}\right)$, to $170^{\circ} \mathrm{C}\left(3^{\circ} \mathrm{C} \mathrm{min}^{-1}\right)$, to $200^{\circ} \mathrm{C}\left(8^{\circ} \mathrm{C} \mathrm{min}^{-1}\right)$, and to $280{ }^{\circ} \mathrm{C}\left(15^{\circ} \mathrm{C} \mathrm{min}-1\right)$, and maintained at $280^{\circ} \mathrm{C}$ for $5 \mathrm{~min}$. The injector port (splitless mode, $0.5 \mathrm{~min}$ ) was at $250^{\circ} \mathrm{C}$. Retention indexes were calculated with reference to $n$ alkanes. All compounds were identified by comparison of both the mass spectra (Wiley 275 library) and the retention index data found in the literature (Adams, 1995).

\section{- GC-FID}

The qualitative analyses of essential oil from $C$. officinalis flowers was carried out using an Agilent 5890 Series II gas chromatograph coupled to an Agilent 3396A integrator equipped with a HP-1 capillary column (12 m X $0.20 \mathrm{~mm}$ I.D., $0.33 \mu \mathrm{m}$ film thickness). Hydrogen was used as the carrier gas $\left(1 \mathrm{~mL} \mathrm{~min}^{-1}\right)$. Chromatographic conditions were identical to those used for GC-MS.

\section{- Steam distillation (SD)}

Plant material (150 g C. officinalis flowers) was hydrodistilled in a Clevenger-type apparatus for $3 \mathrm{~h}$. The oil layers obtained were dried over anhydrous $\mathrm{Na}_{2} \mathrm{SO}_{4}$. The yields $(0.1 \% \mathrm{w} / \mathrm{w})$ were averaged over three experiments, and calculated on the basis of the dry weight of the material. For CG studies, $47 \mathrm{mg}$ of oil dissolved in $1.5 \mathrm{ml}$ of dichloromethane and $1 \mathrm{ml}$ of solution was injected into the GC-MS and the GC-FID spectrometer.

\section{- Headspace solid-phase microextraction (HS-SPME)}

The floral scent of $C$. officinalis was trapped on a $100 \mathrm{~mm}$ polydimethylsiloxane HS-SPME (PDMS) fiber from flower powder (Lee et al., 1988; Jirovets et al., 2002; Kin et al., 2002). $22 \mathrm{~g}$ of finely powdered C. officinalis flowers was placed in a $250 \mathrm{ml}$ Erlenmeyer flask at $20^{\circ} \mathrm{C}$ and equilibrated for $30 \mathrm{~min}$. Next, the SPME fiber was exposed to this atmosphere for $30 \mathrm{~min}$, and then removed and placed in the GC injector for $5 \mathrm{~min}$ at $250^{\circ} \mathrm{C}$.

\section{- Headspace-cold finger (HS-CF) extraction}

$3620 \mathrm{~g}$ of finely powdered $C$. officinalis flowers was placed in a $4000 \mathrm{ml}$ Erlenmeyer flask, which was then closed with a cold finger containing dry ice (Acree and Teranishi 1993). During a 16 -hour period at $20^{\circ} \mathrm{C}$, the cold finger was removed every 10 minutes, and the material deposited on the cold glass surface was scraped and washed with $2 \mathrm{~mL}$ of dichloromethane (spectroscopic quality) into a beaker. The material was dried with anhydrous $\mathrm{Na}_{2} \mathrm{SO}_{4}$ and concentrated at $40{ }^{\circ} \mathrm{C}$ in a distillation unit with a Claisen head, and cold-finger-cooled to $3^{\circ} \mathrm{C}$ to a final volume of $10 \mathrm{ml}$. A volume of $2 \mathrm{ml}$ were injects in HRGC-MS (Rezende et al., 1999; Rezende et al., 2004).

\section{RESULTS AND DISCUSSION}

The yield of oil was determined from dried flowers, in agreement with the methods described in the Farmacopéia Brasileira (1988), in order to provide information useful in future production of a phytomedicine.

The yield found in the literature for the essential oil of Calendula officinalis is $0.3 \%$ (Chalchat et al., 1991) and $0.2 \%$ (PDR, 2000). The present experiment yielded an average of $0.1 \%$ in each oil extraction. In the experiment by Chalchat et al. (1991), calendula cultures from the region of the Massif Central, France, where this plant is native and grows at low temperatures, were evaluated. The likely explanation for this difference in yield is that Calendula is a plant native to cold climates, and now acclimated in southern Brazil where autumn and winter temperatures are higher. 
Analysis of the C. officinalis essential oil extraction techniques by steam distillation, headspace-HS-SPME, or cold-finger analyses and retention indexes, revealed 27 compounds.

Steam-distillation mainly showed sesquiterpene hydrocarbons ( $68.0 \%$ of total area, compounds 1 to 15 and 22 ) and sesquiterpenols (27.0\% of total area, compounds 16 to 21 ) (Figure 1 and Table I). $\delta$-cadinene $(22.5 \%)$ and $\alpha$-cadinol $(20.4 \%)$ were the main compounds, in agreement with Chalchat et al. (1991), who worked with $C$. officinalis from the French Central Massif $(\delta$-cadinene at $12.1 \%$ and $\alpha$-cadinol at $25.5 \%$ ). Radulescu et al. (2000) isolated volatile oils of $C$. officinalis from flowers collected in Bucharest, Romania, by steam distillation and HS; these were analyzed by capillary gas-chromatography-mass

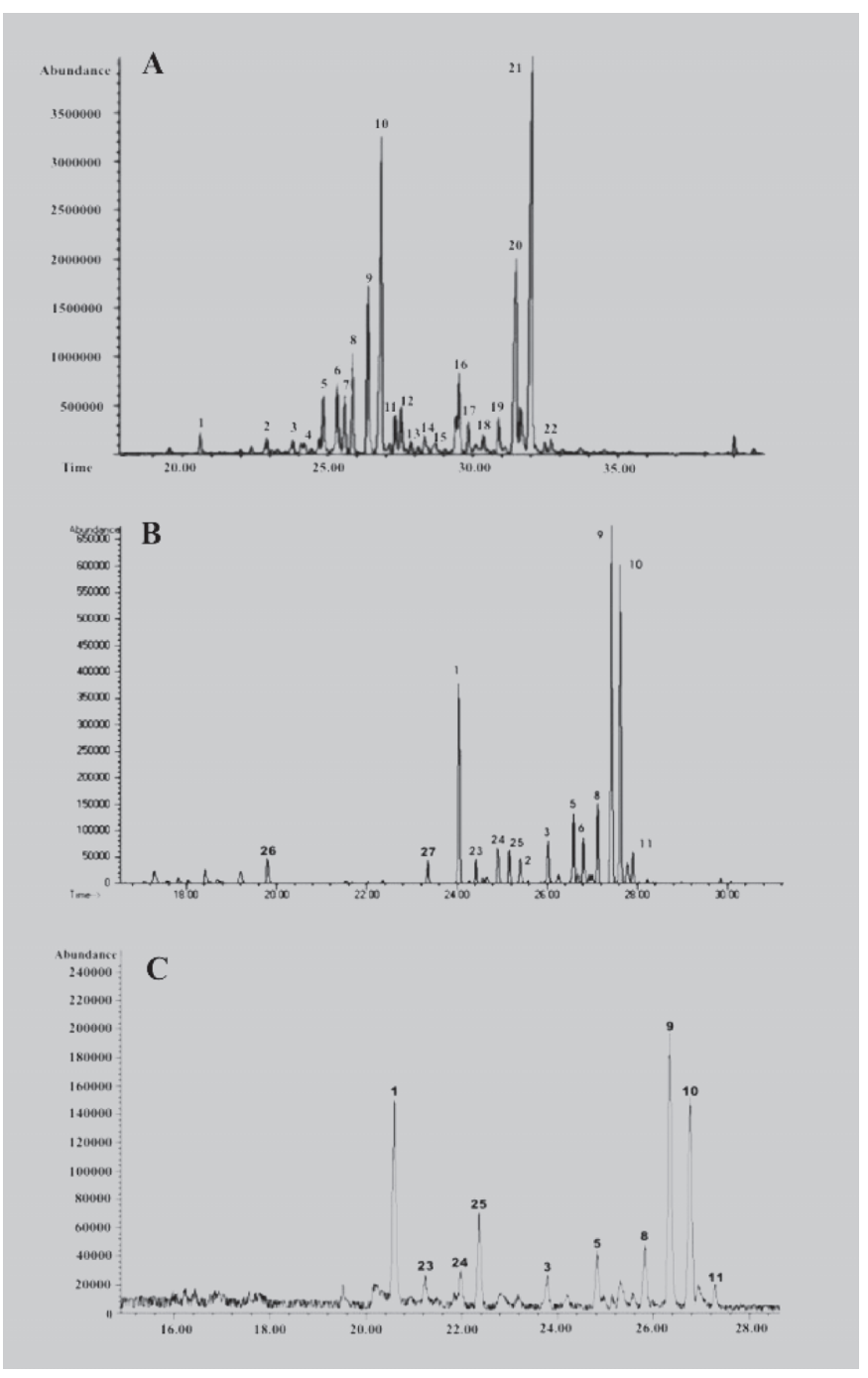

FIGURE 1 - Total ion chromatogram of the Calendula officinalis flowers: (A) volatile oil obtained by Steam distillation (SD); (B) after headspace analysis with HS-SPME; (C) extracted by headspace-cold finger (HS-CF). spectrometry, and had $\alpha$-muurolol (41.5\% of total area) as the chief component.

Only sesquiterpene hydrocarbons were identified by HS-SPME at room temperature using a PDMS fiber and analyzed by GC-MS, as shown in Figure 1 and Table II. The HS-CF extraction showed similar compositions as when using HS-SPME (Figure 1 and Table III).

In the present experiment, three different techniques were used, with different conditions of time and temperature, resulting in the identification of more compounds in steam distillation compared with the HS-SPME and HS-CF methods. By analyses of chromatograms (Figure 1), $\delta$-cadinene appeared as one of the major compounds in all three techniques.

The absence of the sesquiterpene alcohols in the HS-SPME product suggests that polar alcohols and lowmolecular-mass terpenes are not well adsorbed by the PDMS fiber used.

TABLE I - Identification of essential oil compounds from Calendula officinalis flower by steam distillation with Kovats' index $(K i)$

\begin{tabular}{lcccc}
\hline Peak & Compound & Area $\%^{\mathrm{a}}$ & $K i$ & $K i^{*}$ \\
\hline 1 & $\alpha$-copaene & 0.9 & 1365 & 1376 \\
2 & $\alpha$-ionone & 1.5 & 1421 & 1426 \\
3 & $\alpha$-humulene & 1.2 & 1444 & 1454 \\
4 & geranylacetone & 1.6 & 1452 & 1453 \\
5 & $\gamma$-muurolene & 2.3 & 1472 & 1477 \\
6 & $\beta$-ionone & 3.2 & 1484 & 1485 \\
7 & Ledene & 2.3 & 1488 & 1493 \\
8 & $\alpha$-muurolene & 5.6 & 1497 & 1499 \\
9 & $\gamma$-cadinene & 8.9 & 1511 & 1513 \\
10 & $\delta$-cadinene & 22.5 & 1522 & 1524 \\
11 & $\alpha$-cadinene & 0.9 & 1533 & 1538 \\
12 & $\alpha$-calacorene & 2.3 & 1539 & 1542 \\
13 & caryophyllene oxide & 0.5 & 1547 & 1581 \\
14 & copaen-4- $\alpha$-ol & 0.6 & 1566 & 1584 \\
15 & $\beta$-oplopenone & 1.7 & 1568 & 1606 \\
16 & viridiflorol & 2.2 & 1585 & 1590 \\
17 & ledol & 1.3 & 1595 & 1565 \\
18 & 1,10 -di-epi-cubenol & 0.9 & 1608 & 1614 \\
19 & 1 -epi-cubenol & 1.6 & 1621 & 1627 \\
20 & epi- $\alpha$-muurolol & 12.9 & 1639 & 1641 \\
21 & $\alpha$-cadinol & 20.4 & 1654 & 1653 \\
22 & cadalene & 0.8 & 1671 & 1674 \\
\hline
\end{tabular}

${ }^{a}$ Relative percentages of the compounds were obtained electronically from the GC-FID area percent data. $K i$ - was calculated from the GC-MS chromatograms, $K i^{*}$-calculated using Adams data. 
TABLE II - GC-MS identification of the volatile fraction from Calendula officinalis flowers obtained by head spaceHS-SPME with Kovats' index $(\mathrm{Ki})$

\begin{tabular}{lcccc}
\hline Peak & Compound & Area $\%$ & $K i$ & $K i^{*}$ \\
\hline 26 & $\beta$-cyclocitral & 2.1 & 1200 & n.f \\
27 & $\alpha$-cubebene & 1.8 & 1338 & 1351 \\
1 & $\alpha$-copaene & 15.1 & 1364 & 1376 \\
23 & $\beta$-cubebene & 1.8 & 1378 & 1390 \\
24 & $\alpha$-gurjunene & 2.7 & 1396 & 1409 \\
25 & $\beta$-cariophyllene & 2.7 & 1400 & 1418 \\
2 & $\alpha$-ionone & 2.3 & 1420 & 1426 \\
3 & $\alpha$-humulene & 3.9 & 1448 & 1454 \\
5 & $\gamma$-muurolene & 5.3 & 1474 & 1477 \\
6 & $\beta$-ionone & 3.9 & 1485 & 1485 \\
8 & $\alpha$-muuronele & 6.2 & 1500 & 1499 \\
9 & $\gamma$-cadinene & 25.5 & 1516 & 1513 \\
10 & $\delta$-cadinene & 22.1 & 1525 & 1524 \\
11 & $\alpha$-cadinene & 2.3 & 1538 & 1538 \\
\hline
\end{tabular}

The percents were calculated from the GC-FID chromatograms, $\mathrm{Ki}$ - was calculated from the GC-MS chromatograms,

$K i^{*}$-calculated using Adams data.

n.f. $=$ not found

TABLE III - GC-MS identification of the volatile fraction from Calendula officinalis flowers obtained by headspacecold finger with Kovats index $(K i)$

\begin{tabular}{lcccc}
\hline Peak & Compound & Area $\%$ & $K i$ & $K i^{*}$ \\
\hline 1 & $\alpha$-copaene & 18.4 & 1398 & 1376 \\
23 & $\beta$-cubebene & 3.7 & 1343 & 1390 \\
24 & $\alpha$-gurjunene & 4.2 & 1394 & 1409 \\
25 & $\beta$-caryophyllene & 8.6 & 1407 & 1418 \\
3 & $\alpha$-humulene & 3.9 & 1445 & 1454 \\
5 & $\gamma$-muurolene & 4.7 & 1471 & 1477 \\
8 & $\alpha$-muurolene & 5.8 & 1495 & 1499 \\
9 & $\gamma$-cadinene & 24.9 & 1507 & 1513 \\
10 & $\delta$-cadinene & 18.6 & 1519 & 1524 \\
11 & $\alpha$-cadinene & 2.3 & 1531 & 1538 \\
\hline
\end{tabular}

The percents were calculated from the GC-FID chromatograms, $K i$ - was calculated from the GC-MS chromatograms,

$K i^{*}$-calculated using Adams data.

The experiment demonstrated that the HS-SPMS and HS-CF techniques did not replace the traditional technique of steam distillation in the analytical conditions used, because these techniques have different purposes and applications.

\section{RESUMO}

\section{Análise por CG-EM do óleo essencial de Calendula officinalis cultivado no Brasil utilizando-se três diferentes processos de extração}

Terpenos e aromas voláteis das flores de Calendula officinalis cultivados no sudoeste do Brasil foram isolados por arraste a vapor (SD), dedo frio (HS-CF) e micro extração em fase sólida (HS-SPME) acoplada à espectrometria de massas. As flores secas da C. officinalis contêm $0,1 \%$ de óleo essencial e foram identificadas 27 substâncias químicas através do cálculo do índice de Kováts e interpretação dos espectros de massas. As substâncias majoritárias presentes no óleo essencial das flores de C. officinalis, obtido por SD, HS-SPME e HS-CF foram $\delta$-cadinene $(22,5 ; 22,1$ e $18,4 \%) \gamma$-cadinene $(8,9$, 25,4 e $24,9 \%$ ) e $20.4 \%$ de $\alpha$-cadinol foi observado apenas na extração por arraste a vapor.

UNITERMOS: Calendula officinalis L. Cromatografia a gás acoplada a espectrometria de massas. Destilação por arraste a vapor. Dedo frio "cold finger". Microextração em fase sólida.

\section{ACKNOWLEDGEMENTS}

The authors thank the Coordenação de Aperfeiçoamento de Pessoal de Nível Superior (CAPES) and the Conselho Nacional de Desenvolvimento Científico e Tecnológico $(\mathrm{CNPq})$ for the financial support.

\section{REFERENCES}

ACREE, T. E.; TERANISHI, R. Flavor science: Sensible principles and techniques. Washington: American Chemical Society, 1993.351p.

ADAMS, R. P. Identification of essential oil components by gas chromatography/mass spectroscopy. Illinois: Allured Publishing Corporation, 1995. 469p.

CHALCHAT, J. C.; GARRY, R. P. H.; MICHET, A. Chemical composition of essential oil of Calendula officinalis L. (Pot Marigold). Flavour Fragr. J., v.6, p.189-192, 1991.

DELLA-LOGGIA, R.; TUBARO, A.; SOSA, S.; BECKE, R. H.; SAAR, S. T.; ISAAC, D. The role of triperpenoids in the topical antiinflamatory activity of Calendula officinalis flowers. Planta Med., v.60, p.516-520, 1994. 
FARMACOPÉIA BRASILEIRA. 4. ed. São Paulo: Atheneu, 1988. Paginação irregular.

JIROVETS, L.; BUCHBAUER, G.; NGASSOUM, M. B.; GEISSLER, M. Aroma compound analysis of Piper nigrum and Piper guineense essential oil from Cameroon using solid-phase microextraction-gas chromatography, solid-phase microextraction-gas chromatography-mass spectrometry and olfactometry. J. Chromatogr. A, v. 976, p.265- 275, 2002.

KIM, N. S.; LEE, D. S. Comparison of different extraction methods for the analysis of fragrances from Lavandula species by gas chromatography-mass spectrometry. $J$. Chromatogr. A, v.982, p.31-47, 2002.

LEE, S. N.; KIM, N. S.; LEE, D. S. Comparative study of extraction techniques for determination of garlic flavor components by gas chromatography-mass spectrometry. Anal. Bioanal. Chem., v.377, p.749-56, 2003.
PDR for Herbal Medicine. 2. ed. New Jersey: Montvale, 2000. p. 497-499.

RADULESCU, V.; DONEANU, C.; LOLOIU, T. Investigation of chemical composition of Calendula officinalis. Rev. Roum. Chim., v.45, p.271-275, 2000.

RAMOS, A.; EDREIRA,A.; VIZOSO,A.; BETANCOURT, J.; LÓPEZ, M.; DÉCALO M. Genotoxicity of an extract of Calendula officinalis L. J. Ethnopharmacol., v.61, p.49-55, 1988.

REZENDE, C. M.; CORRÊA, V. F. S.; COSTA, A. V. M.; CASTRO, B. C. S. Constituintes químicos voláteis das flores e folhas do pau-brasil (Caesalpinia echinata, Lam.). Quím. Nova, v.27, p.414-416, 2004.

REZENDE, C. M.; LOPES, O. C.; FRAGA, S. R. Principais substâncias responsáveis pelo aroma de mangas comerciais brasileiras identificadas por cromatografia gasosa de alta resolução/ olfatometria/ espectrometria de massas. Quím. Nova, v.22, p.31-36, 1999.

Recebido para publicação em 06 de dezembro de 2006 Aceito para publicação em 06 de julho de 2008 